\title{
Project and test results of new solution for powered roof support for low seams
}

\begin{abstract}
The subject of thin seam exploitation is a complex problem; in reality, it involves several problems such as technical, ergonomic, and economic barriers. They refer mainly to combined longwalls - where a human presence is required at the site; the most important problem is the issue of the limited workspace in longwall roadways. This generates engineering and organizational problems, especially during the launching and removal of the longwall roadways. Having considered the above-mentioned, the Department of Mining, Dressing, and Transport Machines at AGH in Krakow has begun research whose main objective is to develop and test a new structure for a powered support for thin seams. In this paper, virtual models of the new hydraulic roof support and a conception of the structure of a control system were presented as well as the test results of the new construction hydraulic roof support. Research in this field was conducted for the project entitled "Studies of the Development of an Innovative Hydraulic Roof Support for Low Seams". The project is funded by the National Center of Research and Development (NCBiR).
\end{abstract}

Key words: powered roof support, thin seams, control system

\section{INTRODUCTION}

Thin seams with thicknesses that are less than $1.5 \mathrm{~m}$ are critical for energetic security in Poland. Taking into consideration the dwindling hard coal resources, it will be inevitable to opt for the coal found in thin seams. Some sources estimate the reserves of thin seam coal to be approximately one billion coal tons, which will guarantee the continuous mining operation for Polish mines at their present exploitation capacity for at least ten years. It is noticeable that similar tendencies can be observed at examples of other countries in Europe and Asia (Ukraine, China, India, and Indonesia), where thin seams constitute a vast majority of the resource's basis. The subject of thin seam exploitation is not easy, however; in reality, it involves several problems such as technical, ergonomic, and economic barriers [1]. They refer mainly to combined longwalls where a human presence is required at the site, and the most important problem is the issue of limited workspace in longwall roadways. This generates engineering and organizational problems, especially during the launching and removal of the longwall roadways. Then, problems of the transportation and mounting of the machinery and equipment with a mass of several dozen tons can occur. weighing at least several dozens of $\mathrm{Mg}$ occur. Difficulties resulting from the highly limited workspace affect the slow advance of the working team, bring about lower productivity of human labor at a longwall, which results in a decrease in the projected labor time at the site. Climate conditions connected with roadway ventilation also become worse due to the decreasing intersection of the roadways. The limited workspace brings about serious problems related to work safety and ergonomics in a low longwall. Taking into consideration the nature of the above-mentioned problems occurring for sites of low exploitation longwalls 
(especially combined longwalls), their solution should be sought for while developing new machines and equipment that would be better-adjusted to such working conditions [2].

\section{DESIGN OF NEW POWERED ROOF SUPPORT}

Under the conditions of exploiting thin seams, the kinematic structures of shield-type standing supports constitute an essential issue for the improvement of ergonomics and work safety of miners at a longwall. Taking into consideration the exploitation conditions of thin seams as well as the drawbacks of the presently used powered supports in the Department of Mining, Dressing, and Transport Machines, the conception for a new type of powered support has been developed. When compared to the presently applied supports, it offers a larger passage area, a greater ratio of the support load-bearing capacity to its mass, and a decrease in the number of basic elements (structure simplification). The conception of the support has been shown in a simplified diagram in Figure 1 [3]. The resolution consists in connection of the basic section elements; i.e., the roof bar (1) and ground base (2) by means of hydraulic props (3) and angle brace cylinder(s) (5), whereas an advancing cylinder (4) connects the ground brace (2) with the conveyor shut (6). The hydraulic elements are assembled with joints.

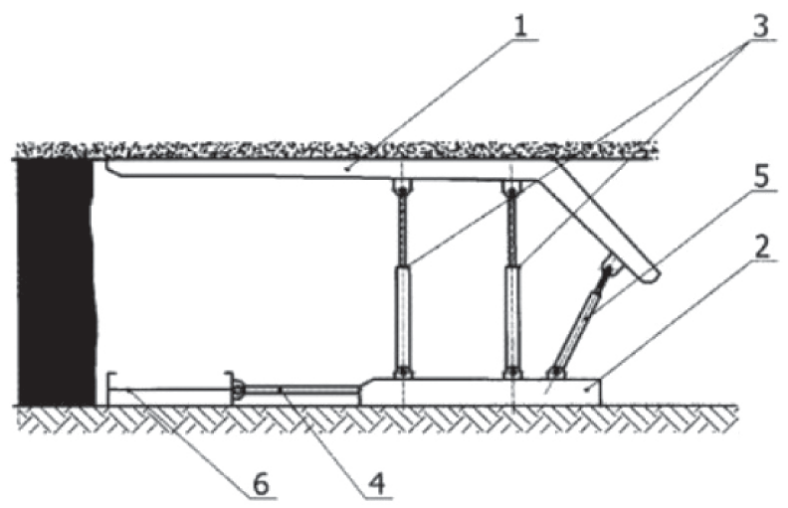

Fig. 1. Conception of new type of powered roof support [3]

An advantage of the presented kinematic structure of support is the vertical movement of the roof bar in the turnaround of the spanning and withdrawing of the support, which nearly eliminates tangents to the friction area of the roof bar. The jointed connection of the props and cylinders with the roof bar and ground brace considerably eliminates the occurrence of bending moments, especially during the turnaround of the support transfer. One of the essential advantages of this solution is the size of the passage area (which is bigger than in the hitherto exploited supports) as well as the simplification of the structure resulting from the elimination of the lemniscates system and conventional roof fall shield. When compared to the presently applied shield-type standing powered supports, the length of the roof bar will also be shorter, which will affect the decrease of the loads that the support structure bears. Consequently, this will allow for the application of supports with smaller overall dimensions. All in all, the resolution combines the virtues of a support with lemniscate handling with the advantages of a conventional standing support, which is becoming a solution of essential utility in the context of the present exploitation problems of thin coal seams. On the basis of the presented conception, numerical simulations have been started $[4,5]$. Its objective was to establish parameters for the structure of the new powered support dedicated for thin seams. An example of a viral model of the support can be seen in Figure 2. In Figure 3 an example of strength analysis of hydraulic support base was presented.

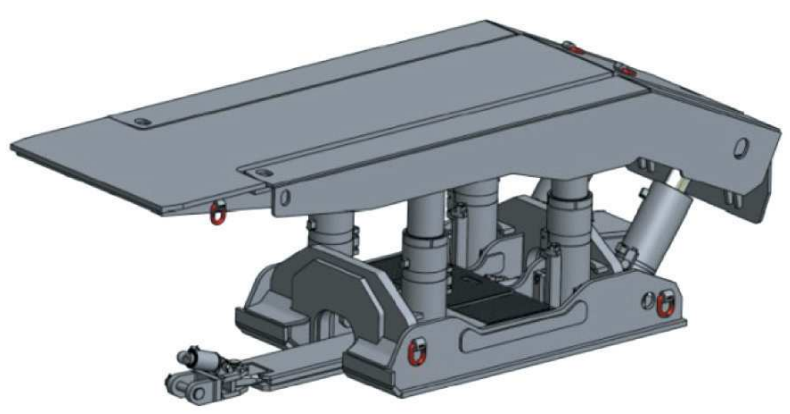

Fig. 2. Virtual model of constructed powered roof support

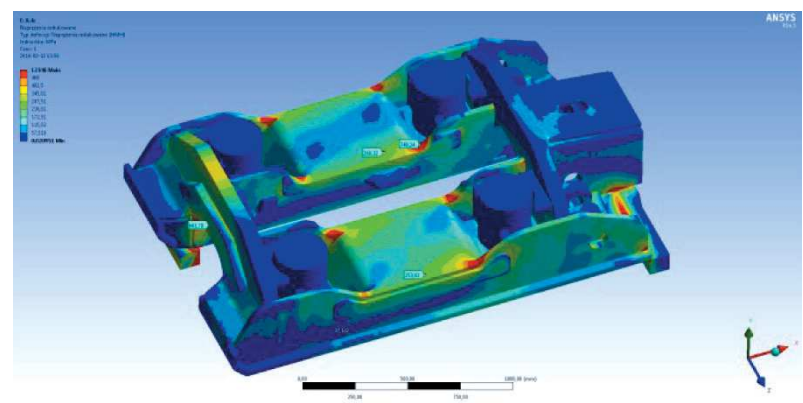

Rys. 3. Strength analysis of hydraulic support base 
The innovative powered support structure of the new type requires several operation turnarounds of the hydraulic control system for realization. This is related to the specific kinematic structure of the section and number of applied hydraulic cylinders (props). The application of the automatic control system should guarantee the monitoring of movement, so the perpendicularity of the props to the ground brace as well as the simultaneous parallelism of the roof bar to the ground brace during support spanning and withdrawing should be maintained. At present in powered longwall supports, complex systems of automatic control are applied. However, their direct adaptation to the solution in question is impossible; this is mainly due to the necessity of applying the dedicated control algorithms adjusted to the specificity of kinematic structure of the new support. All things considered, the research in this scope has focused on the development of algorithms for support control systems - a synthesis of control system hardware with the use of elements that are available on the market. A general block diagram of the new system controlling a single section is shown in Figure 4. As the diagram shows, the system controlling a single section (SCSS) consists of layers of superordinated control and direct control. SCSS is a regulation system that controls the support in response to signals received from the superordinated system of support control (SC). It has been agreed that the system of section regulation will be fully compatible with the superordinated commonly used support control system of a longwall (CWS), so the verified solutions should not be changed.

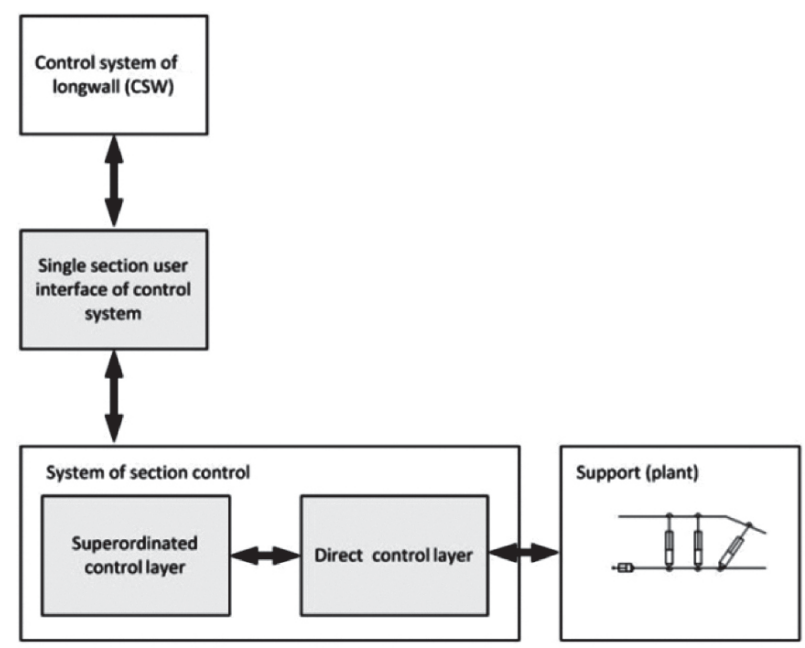

Fig. 4. Block diagram of new system of section steering
The layer of superordinated control (SC) communicates with the superordinated system of longwall control (CSW). It receives command signals such as 'section withdrawal,' 'section spanning,' etc. from the CSW; in return, the CSW receives feedback regarding its condition. The layer of direct control is a part of the control system that, on the basis of signals (commands) from the superordinated part (CS), realizes control of the hydraulic valves in order to complete particular functions. This control layer is responsible for measurement and signal generation. In this layer, the control signals are determined on the basis of the measured displacements of the hydraulic cylinders (main props and angle brace props) and angles of the hydraulic cylinders. They directly control the hydraulic valves of the section.

\section{WORKSTATION RESEARCH ON POWERED SUPPORT SECTION}

In the scope of the project, it has been decided to develop and test three sections of the powered support of the new type (Fig. 5). In Figure 6, the first developed prototype of the support section is shown. The workstation research will be divided into two stages. In the first stage, the cooperation among the three support sections was tested. The objective of this stage was to verify the interaction and performance of the section by its realization of several operating turnarounds; i.e., spanning and withdrawing as well as conveyor and support transfer under conditions approximately similar to the working conditions in a longwall complex system.

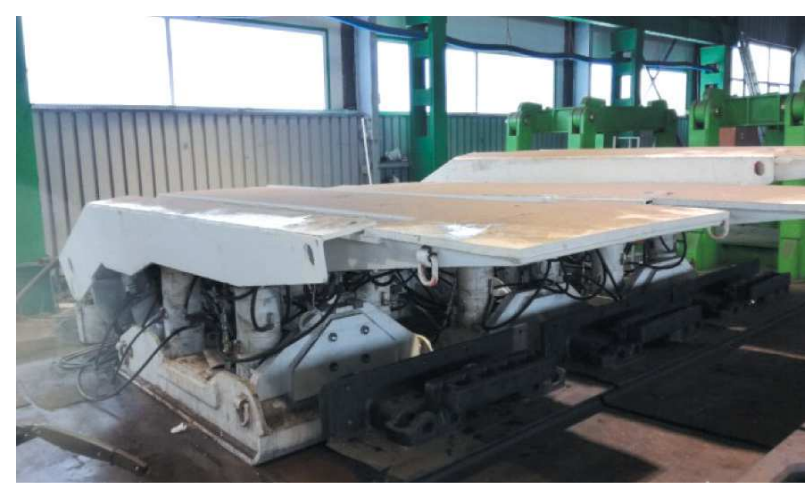

Fig. 5. View of three sections of new powered roof support during first stage of research 


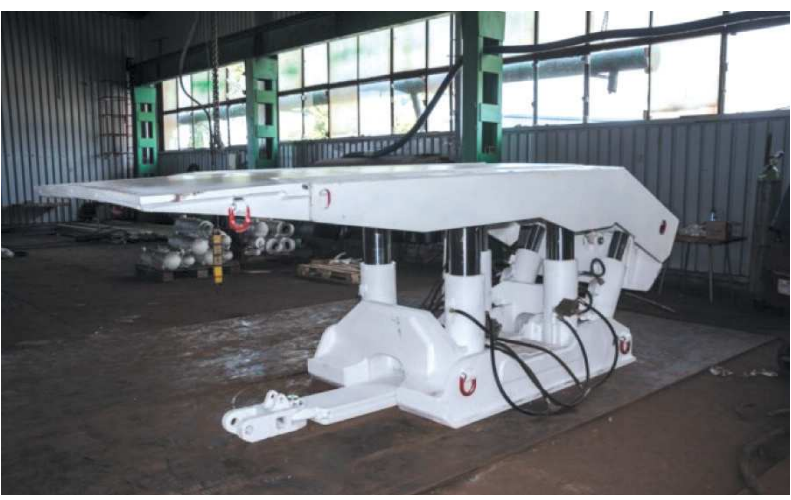

Fig. 6. Prototype of new type of powered roof support

In the second stage of the research, another configuration of loads were checked. the single section behavior conditions of an asymmetric load were carried out. This research allowed us to evaluate the assumed algorithms of a single section control. During the research, the support section was located in a specially designed frame that allowed for the spanning of the support with the maximum load-bearing capacity. An image of this frame is show in Figure 7.

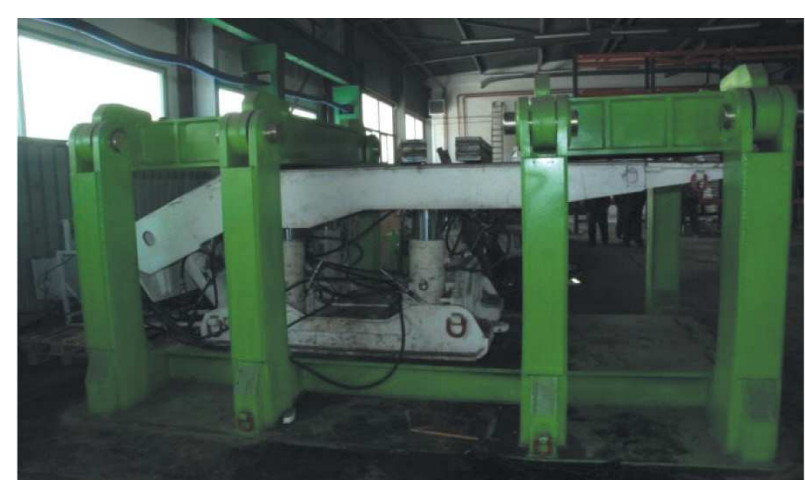

Fig. 7. Support section in the frame

The conditions of the asymmetric load were induced by laying steel bars at the surface of the roof bar; afterwards, the support spanning in the frame structure will follow. In this stage of the research, the support was spanned at the maximum power supply of $32 \mathrm{MPa}$. In Figure 8, one can see an example of a support location within the frame for a selected load-bearing test.

The first stage of the tests allowed us to verify the kinematics of the powered roof support and performed control system. Due to the characteristics of the support section (its kinematic structure), it was particularly important to analyze the displacement of four hydraulic props (SP1, SL1, SP2, and SL2) in the individual section load tests and check the maximum differences in the movement of the hydraulic cylinders. In Figure 9, the locations of the hydraulic cylinders are presented.
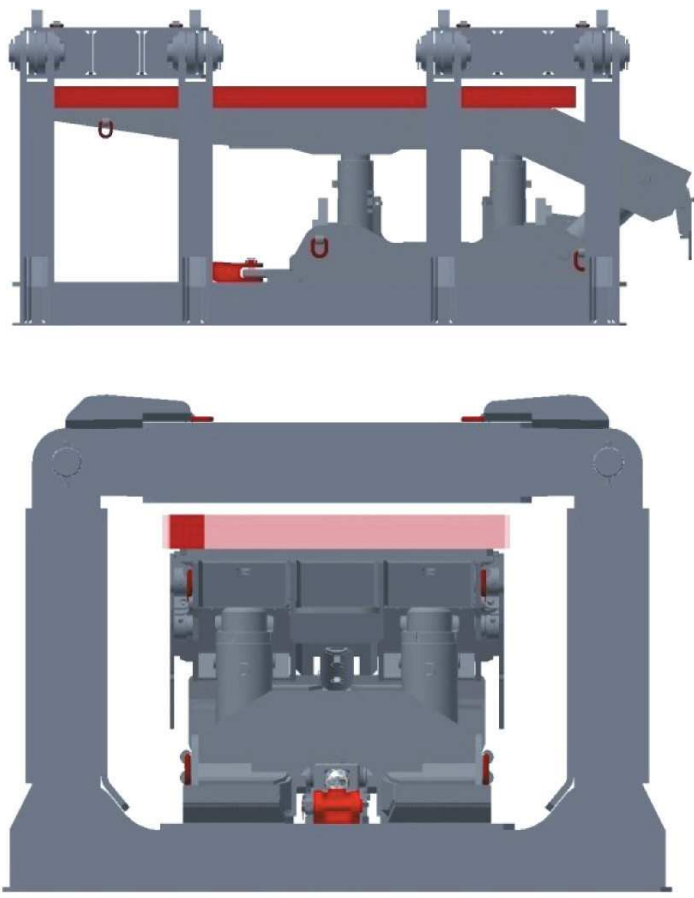

Fig. 8. Examples of loading condition tested in research work-station

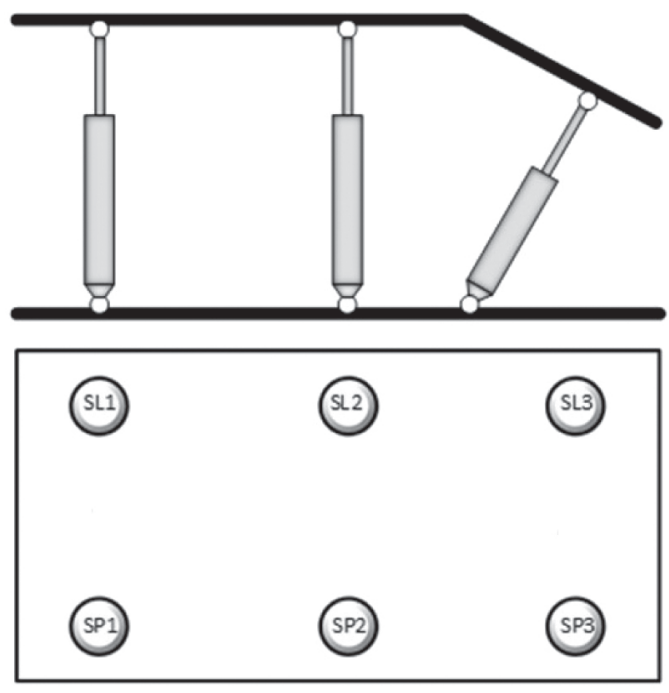

Fig. 9. Location of hydraulic cylinders in tested section

Examples of the movement of the hydraulic cylinders for the second case of the section load can been seen in Figures 10 and 11. The maximum angle of the inclination of the roof bar in the transverse and longitudinal directions does not exceed $2 \%$; this is functionally checked with this system. On the analysis of the pressure waveforms in the tested hydraulic cylinders, the convergence of the tests in a numerical design with the results of the field tests is reported (the adequacy of the load distributions in the hydraulic cylinders of the support section as compared to the characteristics of the support section). 


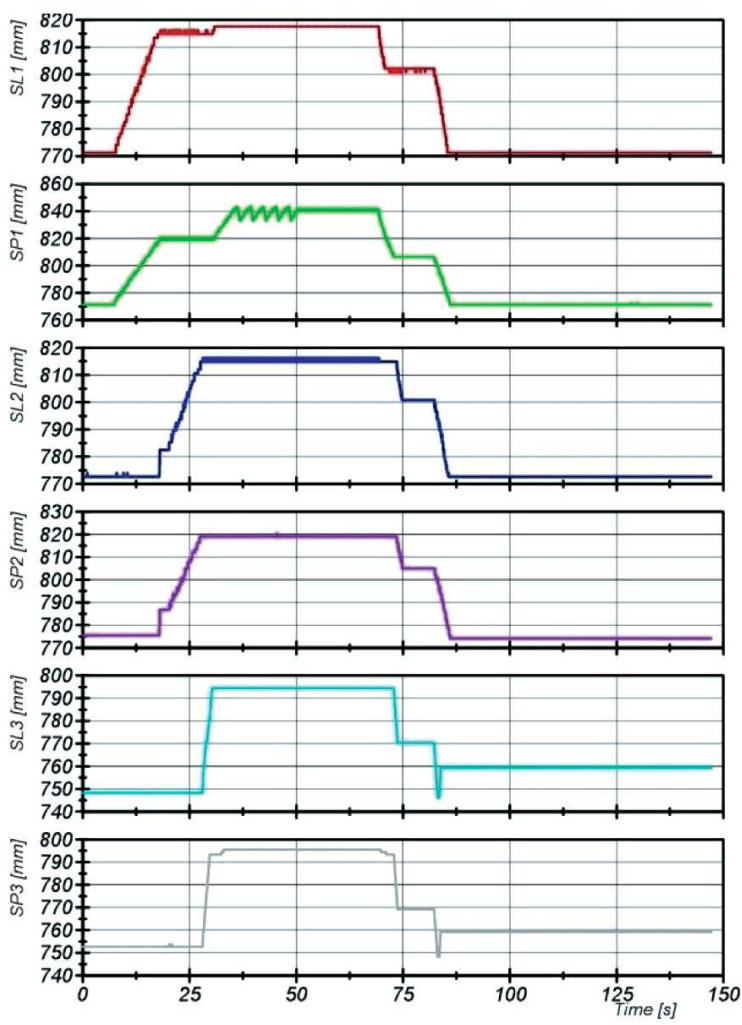

Fig. 10. Displacement courses of hydraulic cylinders during one conducted test

\section{CONCLUSION}

The abundance of thin seams of coal in Poland and around the world encourages us to find new and more efficient technologies for their exploitation. An analysis of the technical and economic limitations connected with thin seam exploitation indicates the development of a new powered support to be one possible way of eliminating the problems. The presented conception of a new type of powered support constitutes a resolution combining the advantages of shield-type standing supports with those of conventional standing supports. As a result, it is possible to improve the essential parameters of a support as far as thin seam exploitation is concerned, including a larger intersection of the passage area as well as a decrease in the support mass as related to the assumed load-bearing capacity of the support. The conducted tests allowed us to positively verify the new construction of the powered roof support. Based on the conducted tests, additional guidelines have been developed for the prototype solution of the support section of a new type.

\section{Acknowledgements}

The project has been realized in the scope of the Program for Applied Research subsidized by

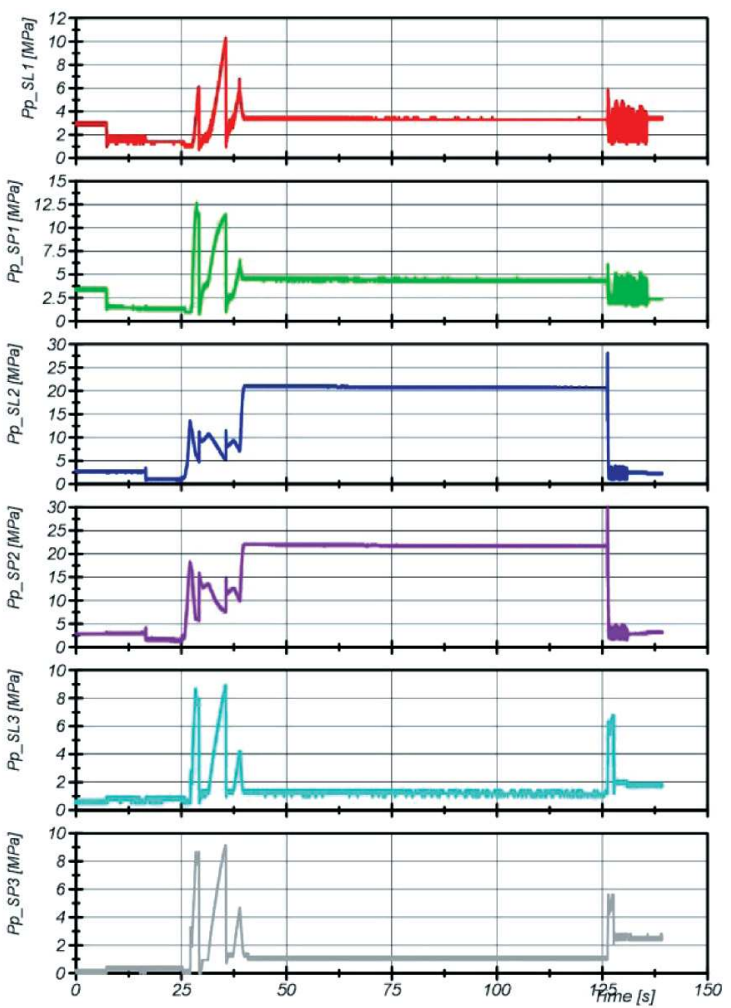

Fig. 11. Pressure course of hydraulic cylinders during one conducted test

the National Center for Research and Development (PBS3/B2/22/2015).

\section{References}

[1] Krauze K., Bołoz Ł., Paszcza H.: Czy warto poszukiwać nowych technologii eksploatacji cienkich pokładów węgla kamiennego w Polsce?, "Transport Przemysłowy i Maszyny Robocze" 2015, 3: 176-184.

[2] Krauze K., Bołoz Ł.: Eksploatacja cienkich pokładów węgla kamiennego. Wybrane problemy eksploatacji węgla i skat zwięzłych, red. K. Krauze, J. Reś, Wydawnictwa AGH, Kraków 2009.

[3] Polish Patent 213664 B1: Sekcja ścianowej zmechanizowanej obudowy podporowej.

[4] Krauze K., Rączka W., Stopka G.: Zmechanizowana obudowa nowego typu do pokładów cienkich, "Maszyny Górnicze" 2016, 4: 34-43.

[5] Krauze K., Rączka W., Stopka G.: Innovative hydraulic roof support for low seams, "Mining Report (Gluckauf)" 2017, 2: 128-136.

KRZYSZTOF KRAUZE, prof. GRZEGORZ STOPKA, Ph.D., Eng.

Department of Machinery Engineering and Transport

WALDEMAR RĄCZKA, D.Sc., Eng. Department of Process Control Faculty of Mechanical Engineering and Robotics AGH University of Science and Technology al. A. Mickiewicza 30, 30-059 Kraków, Poland \{krauze,wraczka,stopka\}@agh.edu.pl 


\title{
Projekt i badania stanowiskowe nowego typu obudowy zmechanizowanej do pokładów cienkich
}

\begin{abstract}
Tematyka eksploatacji pokładów cienkich jest obecnie jednym z głównych obszarów zainteresowań producentów oraz użytkowników zmechanizowanych kompleksów ścianowych. Wynika to z faktu, iż niezależnie od szeregu czynników górniczo-geologicznych, które w różnym stopniu moga wpływać na możliwości techniczne prowadzenia ścian niskich, kwestia wzrostu koncentracji wydobycia z poktadów cienkich jest powiazana przede wszystkim z konstrukcja odpowiednio przystosowanych do ekstremalnie trudnych warunków maszyn zmechanizowanego kompleksu ścianowego. Szczególnie istotna rolę $w$ tego typu warunkach eksploatacyjnych odgrywaja cechy konstrukcyjne obudów zmechanizowanych. W artykule przedstawiono projekt nowej sekcji obudowy zmechanizowanej do pokładów cienkich oraz wyniki badań stanowiskowych z jej udziatem. Prace badawcze $w$ tym zakresie zostaty zrealizowane $w$ ramach projektu pt. „Prace studialne $i$ badawcze nad opracowaniem zmechanizowanej obudowy nowego typu do pokładów cienkich" dofinansowanego z Narodowego Centrum Badań i Rozwoju (NCBiR).
\end{abstract}

Słowa kluczowe: obudowa zmechanizowana, pokłady cienkie, system sterowania

\section{WSTEPP}

Pokłady cienkie, a więc pokłady o miąższości poniżej 1,5 m, mają znaczenie strategiczne dla bezpieczeństwa energetycznego Polski. Mając na uwadze kurczące się zasoby węgla kamiennego, sięgnięcie po węgiel w pokładach cienkich będzie nieuniknione. Według niektórych źródeł zasoby węgla w pokładach cienkich szacuje się na blisko miliard ton, co przy obecnych możliwościach wydobywczych polskich kopalni węgla kamiennego zagwarantuje im ciągłą pracę na co najmniej kilkanaście lat. Warto również zwrócić uwagę na fakt, że podobne tendencje można obserwować na przykładzie niektórych krajów Europy czy Azji (Ukraina, Chiny, Indie, Indonezja), gdzie pokłady cienkie stanowią zdecydowaną większoóć bazy zasobowej. Zagadnienie eksploatacji pokładów cienkich nie jest jednak łatwe i w praktyce napotyka szereg problemów technicznych, ergonomicznych oraz ekonomicznych [1]. Dotyczą one zwłaszcza ścian kombajnowych, gdzie wymagana jest obecność ludzi, a podstawowym problemem jest kwestia ograniczonej przestrzeni roboczej w wyrobisku. Generuje ona problemy techniczne i organizacyjne zwłaszcza przy uruchamianiu czy likwidacji wyrobiska ścianowego. Pojawiają się wtedy problemy transportu i instalacji maszyn oraz urządzeń o masie co najmniej kilkudziesięciu megagramów (ton). Utrudnienia wynikające z mocno ograniczonej przestrzeni roboczej rzutują na spowolnienie przemieszczania się załogi, zmniejszenie wydajności pracy ludzi w ścianie, co w rezultacie prowadzi do spadku dyspozycyjnego czasu pracy ściany. Pogarszają się także warunki klimatyczne związane $\mathrm{z}$ wentylacją wyrobiska, gdyż zmniejszeniu ulega jego przekrój. Ograniczona przestrzeń robocza powoduje w rezultacie poważne problemy związane zarówno z bezpieczeństwem, jak i ergonomią pracy ludzi w ścianie niskiej. Biorąc pod 
uwagę charakter opisywanych wyżej problemów towarzyszących prowadzeniu niskich ścian wydobywczych, zwłaszcza ścian kombajnowych, należy szukać ich rozwiązania w opracowaniu nowych maszyn i urządzeń lepiej dostosowanych do takich warunków pracy [2].

\section{PROJEKT OBUDOWY ZMECHANIZOWANEJ NOWEGO TYPU}

W warunkach eksploatacji pokładów cienkich struktura kinematyczna obudów podporowo-osłonowych stanowi istotny problem dla poprawy ergonomii i bezpieczeństwa pracy ludzi w ścianie. Mając na uwadze uwarunkowania eksploatacji pokładów cienkich oraz wady aktualnie stosowanych obudów zmechanizowanych, w Katedrze Maszyn Górniczych, Przeróbczych i Transportowych opracowano koncepcję obudowy zmechanizowanej nowego typu, która w porównaniu $\mathrm{z}$ aktualnie eksploatowanymi obudowami charakteryzuje się większą strefą przejścia, zwiększonym stosunkiem podporności obudowy do jej masy oraz zmniejszeniem liczby podstawowych elementów (uproszczenie konstrukcji). Koncepcję obudowy w postaci uproszczonego schematu pokazano na rysunku 1 [3]. Istota rozwiązania polega na tym, że elementy podstawowe sekcji, a więc stropnica 1 i spągnica 2 połączone są ze sobą stojakami hydraulicznymi 3 oraz siłownikiem (siłownikami) zastrzałowym 5. Natomiast siłownik przesuwu 4 łączy spągnicę $2 \mathrm{z}$ rynną przenośnika 6 . Elementy hydrauliczne są mocowane przegubowo.

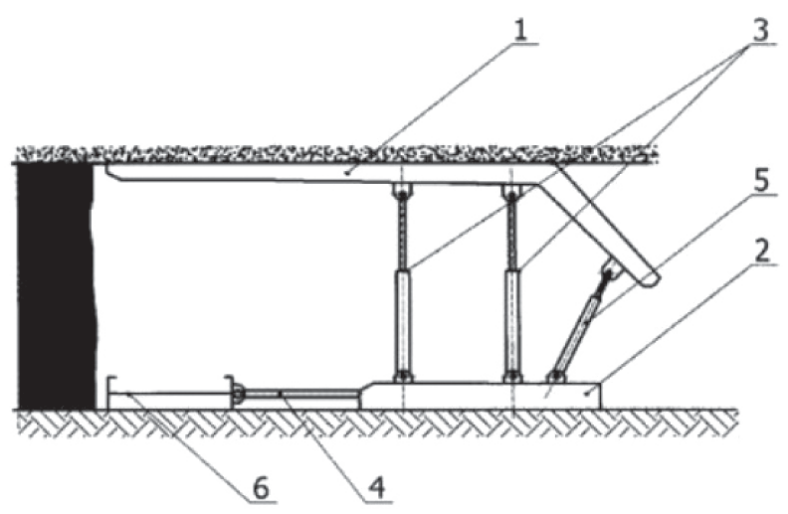

Rys. 1. Koncepcja obudowy nowego typu [3]

Zaletą przedstawionej struktury kinematycznej obudowy jest pionowy ruch stropnicy w cyklu rozpierania i rabowania obudowy, co praktycznie eliminuje siły tarcia styczne do powierzchni stropnicy.
Połączenie przegubowe stojaków i siłowników ze stropnicą i spągnicą $\mathrm{w}$ znacznym stopniu eliminuje powstanie momentów gnących, zwłaszcza w cyklu przekładki obudowy. Do podstawowych zalet nowego rozwiązania należy wielkość strefy przejścia, większa niż w dotychczas eksploatowanych obudowach oraz uproszczenie konstrukcji przez wyeliminowanie układu lemniskatowego oraz klasycznej osłony odzawałowej. W porównaniu ze stosowanymi obecnie obudowami podporowo-osłonowymi skróceniu ulegnie także długość stropnicy obudowy, co przyczyni się do zmniejszenia obciążeń działających na konstrukcję obudowy, a więc pozwoli na zastosowanie podpór o mniejszych gabarytach. Reasumując, przedmiotowe rozwiązanie łączy w sobie zalety obudowy z prowadzeniem lemniskatowym oraz walory klasycznej obudowy podporowej, a w kontekście aktualnych problemów eksploatacji cienkich pokładów węgla staje się rozwiązaniem o istotnych walorach użytkowych. Na podstawie przedstawionego, uproszczonego schematu ideowego rozpoczęto badania modelowe, których celem było sparametryzowanie konstrukcji nowej, zmechanizowanej obudowy do pokładów cienkich [4, 5]. Przykładowy widok wirtualnego modelu obudowy pokazano na rysunku 2 . W ramach badań modelowych przeprowadzono wiele testów symulacyjnych nowej konstrukcji sekcji. Przykładowe wyniki badań wytrzymałościowych zaprezentowano na rysunku 3.

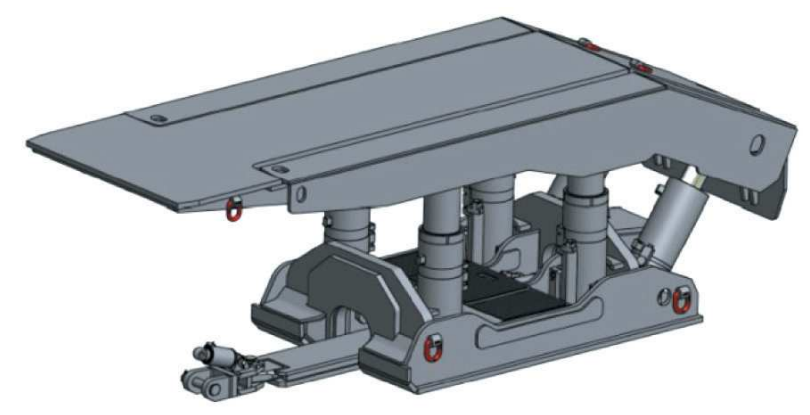

Rys. 2. Widok przestrzenny modelu 3D obudowy

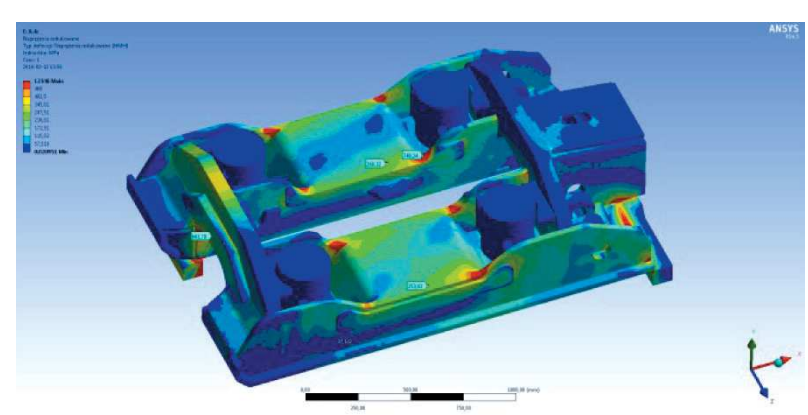

Rys. 3. Rozkład naprężeń zredukowanych $w$ konstrukcji spagnicy 
Innowacyjna konstrukcja zmechanizowanej obudowy nowego typu wymaga wykorzystania do realizacji poszczególnych cykli pracy elektrohydraulicznego systemu sterowania. Wynika to ze specyficznej struktury kinematycznej sekcji oraz liczby zastosowanych siłowników hydraulicznych (stojaków). Zastosowanie automatycznego systemu sterowania powinno gwarantować kontrolę ruchu tak, aby zapewnić prostopadłość stojaków do spągnicy i jednoczesną równoległość położenia stropnicy do spągnicy zarówno w czasie rabowania, jak i rozpierania obudowy. Aktualnie w zmechanizowanych obudowach ścianowych stosowane są złożone układy automatycznego sterowania. Jednak ich bezpośrednia adaptacja do przedmiotowego rozwiązania jest niemożliwa głównie ze względu na konieczność stosowania specjalnych algorytmów sterowania dostosowanych do specyfiki kinematycznej struktury nowej obudowy. $\mathrm{Z}$ tego względu prace badawcze w tym zakresie skoncentrowano na opracowaniu algorytmów sterowania obudową oraz syntezą układu sterowania, wykorzystując elementy dostępne na rynku. Ogólny schemat blokowy nowego układu sterowania pojedynczą sekcją pokazano na rysunku 4.

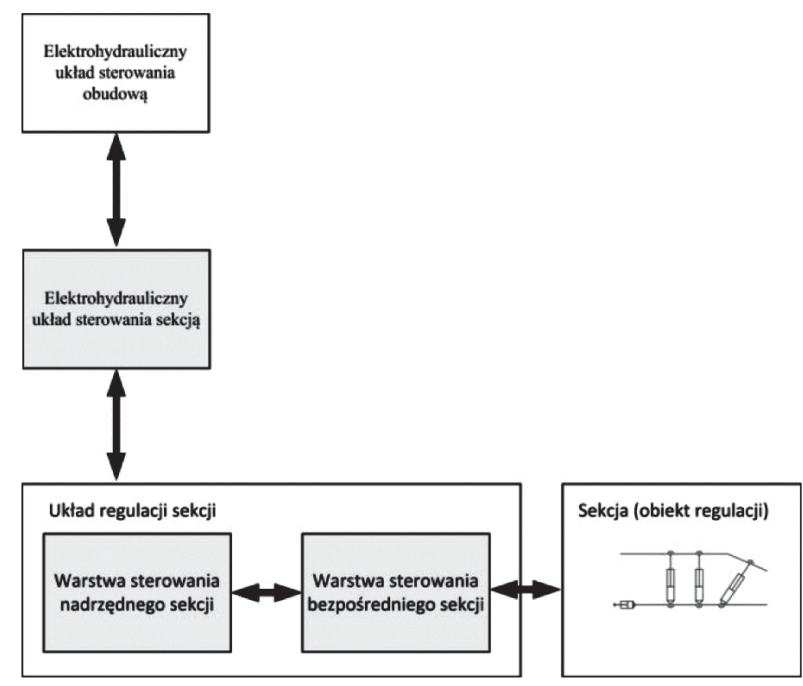

Rys. 4. Schemat blokowy nowego układu sterowania sekcja

Jak wynika ze schematu, układ sterowania pojedynczą sekcją (URS) jest złożony z warstwy sterowania nadrzędnego i bezpośredniego. URS jest układem regulacji, który bezpośrednio steruje obudową na podstawie sygnałów otrzymanych z nadrzędnego systemu sterowania obudową (EUSS). Przyjęto, że układ regulacji sekcji (URS) będzie w pełni kompatybilny z nadrzędnym, standardowo stosowanym systemem sterowania obudową (EUSS), tak aby nie zmieniać wypróbowanych już w praktyce rozwiązań.

Warstwa sterowania nadrzędnego komunikuje się z nadrzędnym systemem sterowania obudową (EUSS). Ze sterownika EUSS otrzymuje sygnały sterujące, np. rabowanie sekcji, rozpieranie sekcji itd., a zwrotnie EUSS otrzymuje informacje o jej stanie. Warstwa sterowania bezpośredniego to część układu regulacji, która na podstawie sygnałów (rozkazów) z części nadrzędnej realizuje sterowanie zaworami hydraulicznymi w celu wykonania określonych funkcji. Ta warstwa sterowania jest odpowiedzialna za pomiar i generowanie sterowań. W tej warstwie na podstawie zmierzonych przemieszczeń siłowników hydraulicznych (stojaków głównych i stojaków zastrzałowych), kątów nachylenia stojaków wyznaczane są sygnały sterujące bezpośrednio zaworami hydraulicznymi sekcji.

\section{BADANIA STANOWISKOWE SEKCJI OBUDOWY NOWEGO TYPU}

W ramach projektu zaplanowano wykonanie i przebadanie trzech sekcji zmechanizowanej obudowy nowego typu (rys. 5). Na rysunku 6 pokazano pierwszy wykonany prototyp przedmiotowej sekcji obudowy. Badania stanowiskowe zostały podzielone na dwie fazy. W pierwszej fazie przeprowadzono badania współpracy trzech sekcji obudowy. Celem tej fazy badań było sprawdzenie współdziałania sekcji w sytuacji realizacji poszczególnych cykli pracy, takich jak rozpieranie, rabowanie oraz przekładka przenośnika i obudowy.

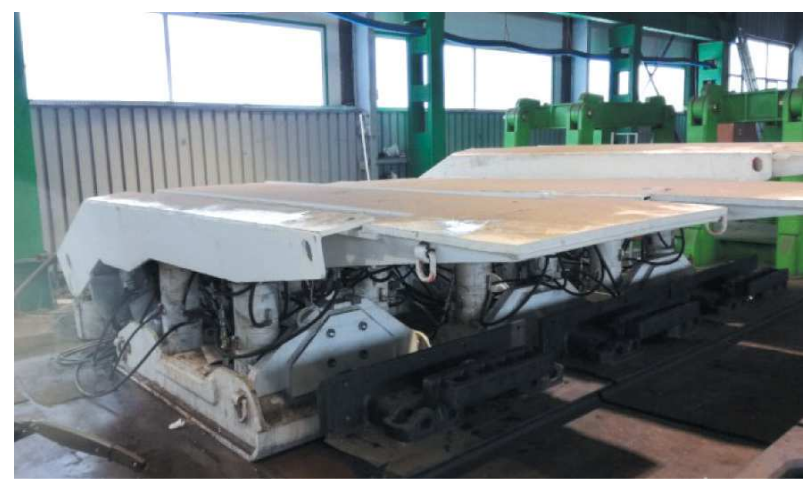

Rys. 5. Widok trzech sekcji obudowy podczas pierwszego etapu badań 


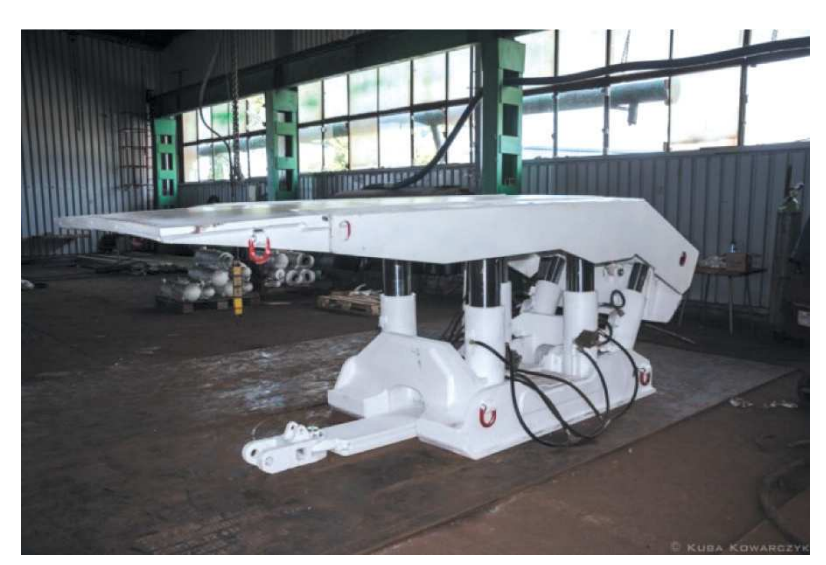

Rys. 6. Widok prototypu sekcji obudowy nowego typu

W kolejnym etapie przebadano zachowanie pojedynczej sekcji w warunkach obciążeń asymetrycznych. Badanie to umożliwiło ocenę przyjętych algorytmów sterowania pojedynczą sekcją. W czasie badań sekcja obudowy znajdowała się w specjalnie zaprojektowanej ramie, która pozwoliła na rozparcie obudowy z maksymalną podpornością. Widok tej ramy zaprezentowano na rysunku 7. Stany obciążenia asymetrycznego zostały wywołane przez ustawienie na powierzchni stropnicy belek stalowych, a następnie rozparcie obudowy w konstrukcji ramy. W tej części badań obudowa rozpierana była $\mathrm{z}$ maksymalnym ciśnieniem zasilania wynoszącym $32 \mathrm{MPa}$. Na rysunku 8 pokazano przykładowe ustawienie obudowy $\mathrm{w}$ ramie stanowiska podczas wybranego testu obciążeniowego.

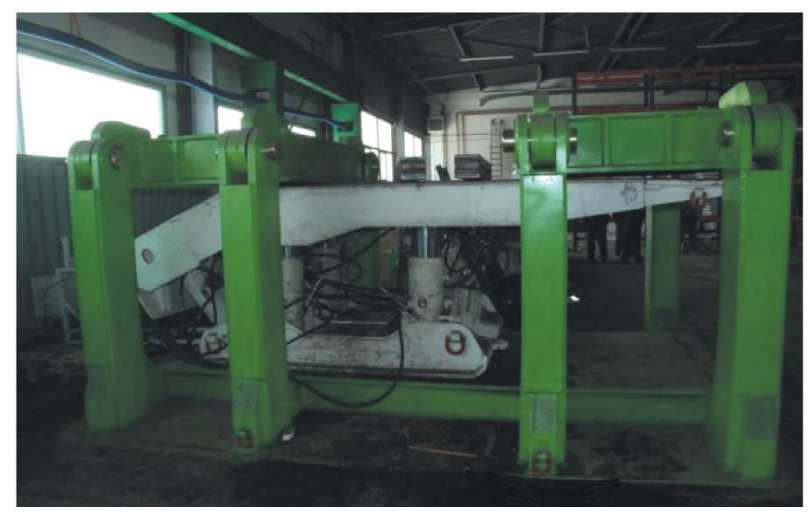

Rys. 7. Badania sekcji w ramie

Badania stanowiskowe przeprowadzone w ramach pierwszej fazy testów pozwoliły na pozytywną weryfikację kinematyki sekcji oraz opracowanego układu sterowania obudową. Z uwagi na charakterystykę obudowy (jej strukturę kinematyczną) szczególnie istotna dla oceny wyników badań była analiza przemieszczeń tłoczysk czterech głównych stojaków (SP1, SL1, SP2, SL2) w poszczególnych testach obciążeń sekcji i sprawdzenie na ich podstawie maksymalnych różnic w wysuwie tłoczysk tych stojaków. Na rysunku 9 pokazano rozmieszczenie stojaków w prototypowej sekcji.
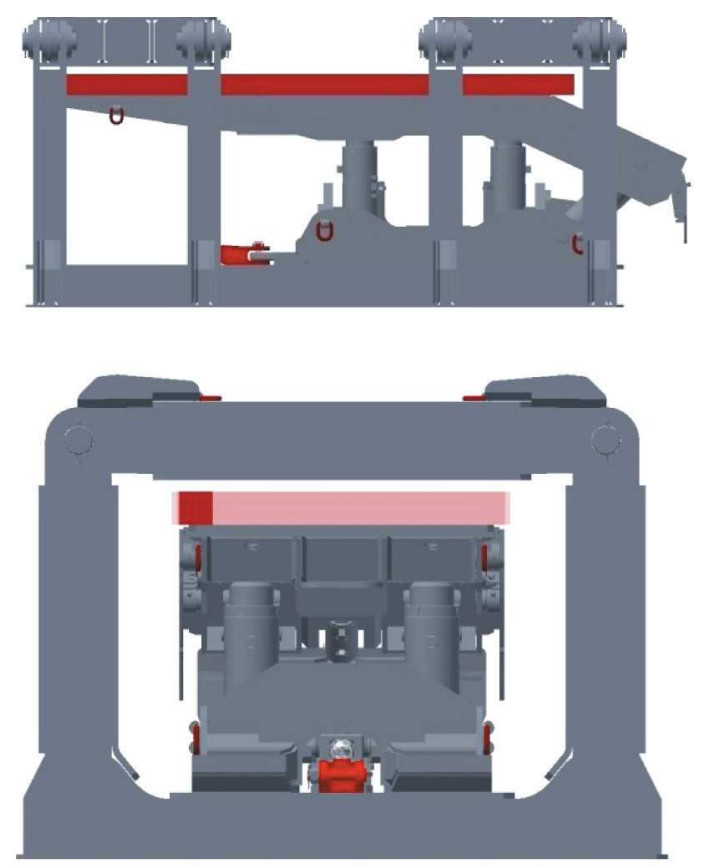

Rys. 8. Przykładowa konfiguracja podparć sekcji podczas drugiego etapu badań

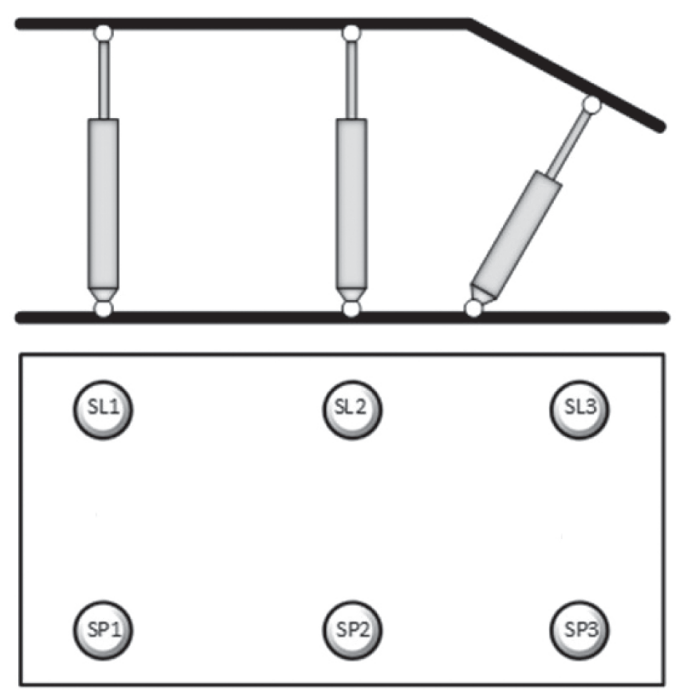

Rys. 9. Rozmieszczenie stojaków sekcji obudowy

Przykładowe przebiegi zarejestrowane w czasie jednego z testów sekcji obudowy pokazano na rysunkach 10 i 11 . Na podstawie zarejestrowanych w czasie badań przebiegów przemieszczeń siłowników 
hydraulicznych możliwe było oszacowanie maksymalnego kąta nachylenia stropnicy w płaszczyźnie wzdłużnej i poprzecznej. W czasie badań kąt ten dla różnych wariantów podparcia sekcji nie przekroczył $2 \%$, co potwierdza zalety funkcjonalne zastosowanego systemu sterowania sekcją (rys. 10). Na podstawie

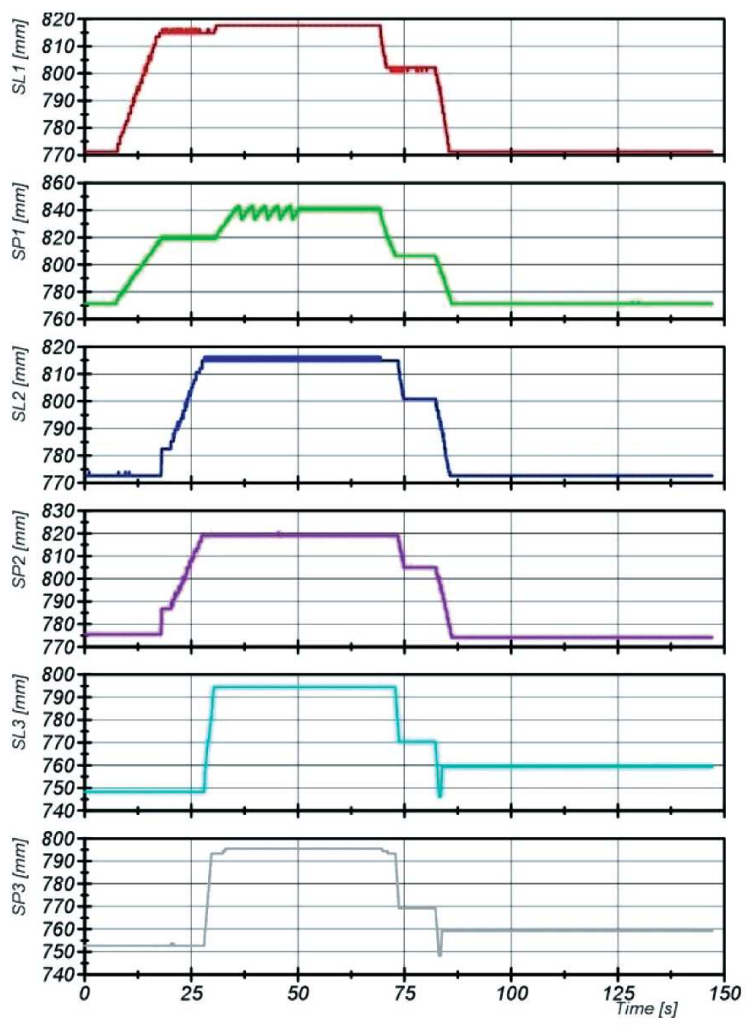

Rys. 10. Przebiegi czasowe przemieszczeń tłoczysk stojaków sekcji w czasie jednego z przeprowadzonych testów

\section{PODSUMOWANIE}

Wzrost koncentracji wydobycia węgla z pokładów cienkich zarówno w Polsce, jak i na świecie skłania do poszukiwania nowych i bardziej efektywnych technologii ich eksploatacji. Szczególnie istotne znaczenie w trudnych warunkach eksploatacyjnych pokładów cienkich mają cechy konstrukcyjne obudów zmechanizowanych. Analiza zagadnień technicznych i ekonomicznych towarzyszących eksploatacji pokładów cienkich wskazuje, że opracowanie nowej konstrukcji obudowy zmechanizowanej może przyczynić się do zmniejszenia dotychczasowych ograniczeń. Przedstawiona w artykule koncepcja sekcji obudowy zmechanizowanej łączy w sobie zalety aktualnie stosowanej obudowy podporowo-osłonowej z zaletami obudowy podporowej. W związku z powyższym nowa konstruk- analizy przebiegów ciśnień w stojakach badanej sekcji można stwierdzić zbieżność opracowanych w ramach projektu modeli numerycznych sekcji z rezultatami badań stanowiskowych (adekwatność rozkładu sił w poszczególnych stojakach sekcji w odniesieniu do charakterystyki podparcia obudowy) (rys. 11).

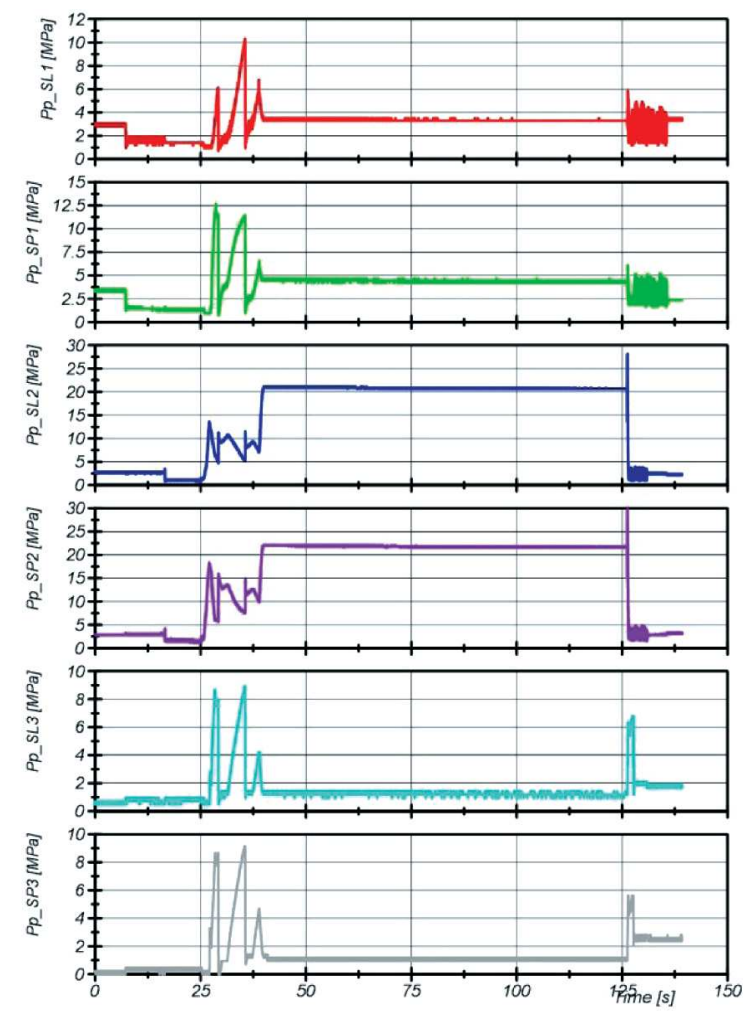

Rys. 11. Przebiegi czasowe ciśnień w stojakach sekcji $w$ czasie jednego z przeprowadzonych testów

cja sekcji obudowy będzie charakteryzować się, w porównaniu $\mathrm{z}$ aktualnie stosowanymi obudowami, większą strefą przejścia, mniejszą masą oraz zwiększonym stosunkiem podporności do masy sekcji. Przeprowadzone badania stanowiskowe pozwoliły na pozytywna weryfikację konstrukcji sekcji i umożliwiły zdefiniowanie końcowych założeń i wytycznych dla prototypu sekcji obudowy nowego typu, zwłaszcza w zakresie układu sterowania sekcja.

\section{Podziękowania}

Publikacja została opracowana w ramach projektu nr PBS3/B2/22/2015 pt. „Prace studialne i badawcze nad opracowaniem zmechanizowanej obudowy nowego typu do pokładów cienkich" dofinansowanego ze środków Narodowego Centrum Badań i Rozwoju. 


\section{Literatura}

[1] Krauze K., Bołoz Ł., Paszcza H.: Czy warto poszukiwać nowych technologii eksploatacji cienkich poktadów węgla kamiennego w Polsce?, „Transport Przemysłowy i Maszyny Robocze" 2015, 3: 176-184.

[2] Krauze K., Bołoz Ł.: Eksploatacja cienkich poktadów węgla kamiennego, w: Wybrane problemy eksploatacji węgla i skat zwięztych, red. K. Krauze, J. Reś, Wydawnictwa AGH, Kraków 2009.

[3] Patent PL 213664 B1: Sekcja ścianowej zmechanizowanej obudowy podporowej.

[4] Krauze K., Rączka W., Stopka G.: Zmechanizowana obudowa nowego typu do pokładów cienkich, "Maszyny Górnicze” 2016, 4: 34-43.

[5] Krauze K., Rączka W., Stopka G.: Innovative hydraulic roof support for low seams, „Mining Report (Gluckauf)” 2017, 2: 128-136. prof. dr hab. inż. KRZYSZTOF KRAUZE

dr inz. GRZEGORZ STOPKA

Katedra Inżynierii Maszyn i Transportu

dr hab. inż. WALDEMAR RĄCZKA

Katedra Automatyzacji Procesów

Wydziat Inżynierii Mechanicznej i Robotyki

AGH Akademia Górniczo-Hutnicza

im. Stanisława Staszica $w$ Krakowie

al. A. Mickiewicza 30, 30-059 Kraków

\{krauze,wraczka,stopka\}@agh.edu.pl 